\title{
MEASUREMENT OF PROTEIN MOBILITY IN SODIUM DODECYL SULPHATE POLYACRYLAMIDE GEL ELECTROPHORESIS
}

\author{
R. RAMASAMY, N. SUBANESAN AND MANTHIRI RAMASAMY \\ Department of Life Sciences, Institute of Fundamental Studies, Hantana Road, Kandy.
}

(Date of receipt $\quad:$ 10 February 1992)
(Date of acceptance $:$ 18 June 1992)

\section{Introduction}

Sodium dodecyl sulphate - polyacrylamide gel electrophoresis (SDS-PAGE), with the Laemmli discontinuous buffer system ${ }^{1}$ is widely used for molecular weight (m.wt) estimation and separation of proteins. The determination of $m$.wts. and identification of specific proteins often relies on accurate measurement of the mobilities of proteins. When the mobilities of proteins in cell and tissue lysates are being determined, it is not possible to ensure that all the proteins are present in approximately the same concentration that permits optimal resolution within the loading capacity of the gel. In seeking to identify minor components in a mixture, the more prevalent proteins may be loaded in amounts greater by one or even two orders of magnitude. Consequently, the question arises as to whether the leading edge, middle or trailing edge of a broad protein band detected by protein staining gives a more accurate estimation of its real mobility.

\section{Materials and Methods}

High m.wt marker proteins (myosin, $\beta$-galactosidase, phosphorylase $b$, bovine serum albumin, ovalbumin and carbonic anhydrase), low m.wt marker (bovine serum albumin, ovalbumin, glyceraldehyde 3-phosphate dehydrogenase, carbonic anhydrase, trypsinogen, trypsin inhibitor and lactalbumin) and human immunoglobulin (IgG) were obtained from Sigma, St. Louis, Mo, USA. The inarker proteins were dissolved in reducing Laemmli buffer ${ }^{1}$ at a concentration of $0.5 \mathrm{mg} \mathrm{ml}^{-1}$. IgG was dissolved in the buffer at $4 \mathrm{mg} \mathrm{m}^{-1}$. Serial dilutions of the proteins in Laemmli buffer were made and equal aliquots carefully loaded into wells of the same capacity in a $4 \%$ Laemmli stacking gel and resolved by SDS-PAGE using a 10\% separating gel. Polyacrylamide gel slabs were prepared as described by Laemmli. ${ }^{1}$ Gels were prepared from a stock solution containing $30 \%$ by weight of acrylamide and $0.8 \%$ by weight of $\mathrm{N}, \mathrm{N}^{1}$. bis-methylene acrylamide. The separating gel contained $0.375 \mathrm{M}$ Tris- $\mathrm{HCl}(\mathrm{pH} 8.8)$ and $0.1 \%$ SDS. The gels were polymerized using $0.025 \%$ by volume of tetraethyl ethylenediamine (TEMED) and ammonium persulphate. The electrode buffer contained $0.025 \mathrm{M}$ Tris- $\mathrm{HCl}$ (pH 6.8), $0.192 \mathrm{M}$ glycine and $0.1 \%$ SDS. The sarple 
buffer contained $0.0625 \mathrm{M}$ Tris- $\mathrm{HCl}$ (pH 6.8), $2 \%$ SDS, $10 \%$ glycerol, $5 \%$ of 2 -mercaptoethanol and $0.001 \%$ bromophenol blue as a dye. Stacking was performed at $30 \mathrm{~V}$ and separation at $120 \mathrm{~V}$ in a Hoeffer slab gel electrophoresis apparatus. The gels were stained in $0.5 \%$ Coomassie blue, destained in $10 \%$ acetic acid with $45 \%$ methanol, dried and photographed.

\section{Results}

Figure 1 shows the resluts of a typical experiment with mixtures of marker proteins. Significant overloading and hence band distortion becomes evident with approximately $1.25 \mu \mathrm{g}$ of protein in each band under the conditions used for electrophoresis. Increasing the amount of loaded proteins form $600 \mathrm{ng}$ to $10 \mu \mathrm{g}$ (high m.wt. mixture) and $150 \mathrm{ng}$ to $20 \mu \mathrm{g}$ (low m.wt. mixture) leads to increasing mobility of the leading edge. The mobility of the trailing edge of the protein bands on the other hand remains relatively constant in comparison. Similar observations were made with the heavy chain of IgG (Figure 2). The m.wts. estimated for the IgG heavy chain using mobilities of the leading and trailing edges of the band in the lane containing $50 \mu \mathrm{g}$ IgG, and sufficiently small quantities of m.wt standards to avoid overloading, were 44 and $55 \mathrm{kDa}$ respectively. The use of the middle of the heavy chain band gave a value of $48.5 \mathrm{kDa}$ for the m.wt. A commonly accepted value for the m.wt. of the human IgG heavy chain, based on the electrophoresis of small quantities of heavy chains when overloading effects are absent, is $55 \mathrm{kDa}$.

A general upward skewing of bands towards the sides of the gel, due to differences in current flowing between the middle of the gel and the sides, is sometimes seen in electrophoresis eg. Lanes 1,2 and 3 in Figure 1. However, such effects are not relevant to the main observation reported here since the migration of all bands, including the dye front, are similarly affected at the sides of the gel.

\section{Discussion}

When protein mobilities are measured after PAGE authors do not clearly state which part of a broad protein band is being used. ${ }^{1}$ This is because it is an accepted practice to measure the centre of the band for calculating m.wts. The results presented here show that the trailing edge of stained bands of nine different proteins viz. myosin, $\beta$-galactosidase, phosphorylase $\mathrm{b}$, bovine serum albumin, glyceraldehyde 3-phosphate dehydrogenase, ovalbumin, carbonic anhydrase, trypsinogen and heavy chains of IgG are best for estimating mobilities and hence m.wts. Significant errors, as illustrated in the case of the IgG heavy chain, can be introduced by using either the middle or the leading edge of overloaded proteins bands for this purpose. The reasons for the observed phenomenon may be complex and are probably related to overloading the sieving capacity of the gel. The interpretation of the mobilities of similarly overloaded protein from autoradiography and enzymatically stained Western blots will depend on the degree of band broadening caused by the radiation and diffusion of coloured 


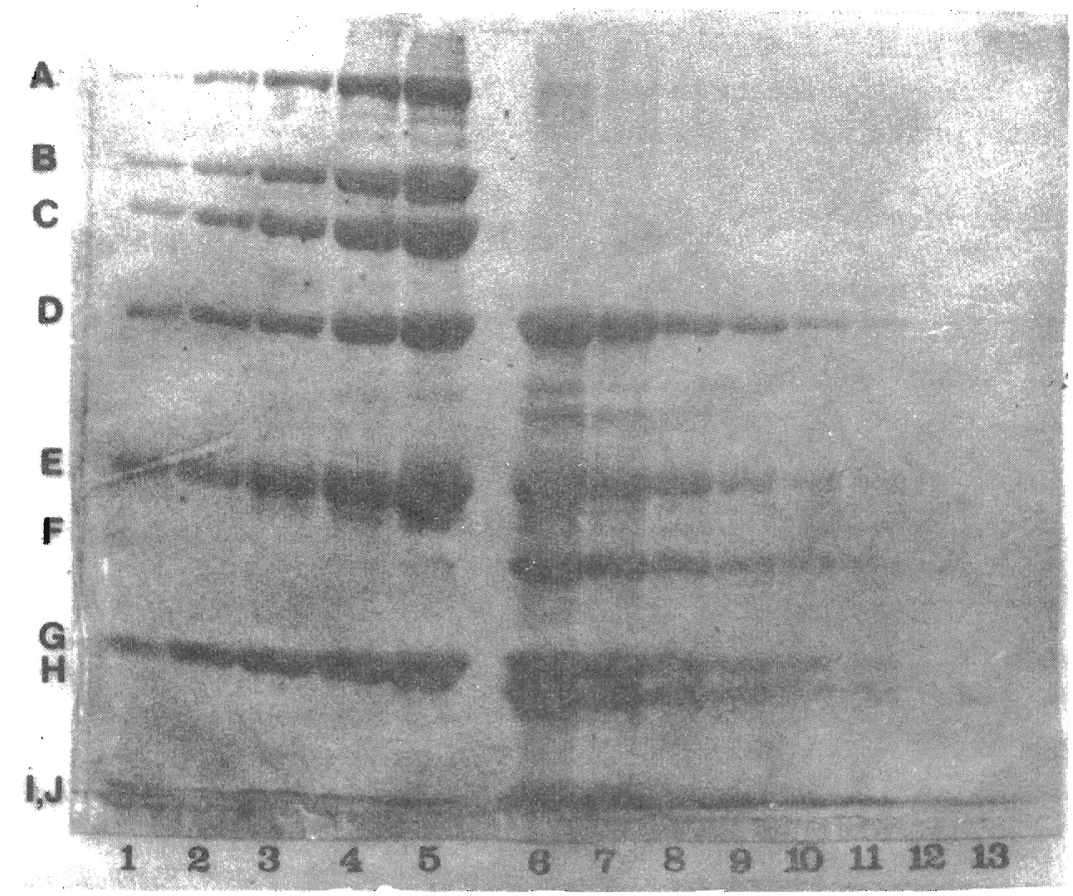

Figure 1: Variation in mobility of A-Myosin, $-\beta$ galactosidase, C-phosphorylase b, D-serum albumin, E-ovalbumin, F-glyceraldehyde - 3-phosphate dehydrogenase, G-carbonic anhydrase, H-trypsinogen, I-trypsin inhibitor and J-lactalbumin with protein concentration. Lanes 1.5 were loaded with $600 \mathrm{ng}, 1.25 \mu \mathrm{g}, 2.5 \mu \mathrm{g}, 5 \mu \mathrm{g}$, and $10 \mu \mathrm{g}$ respectively of each of the high m.wh marker proteins while lanes 6-13 were loaded with 20 $\mu \mathrm{g}, 10 \mu \mathrm{g}, 5 \mu \mathrm{g}, 2.5 \mu \mathrm{g}, 1.25 \mu \mathrm{g}, 600 \mathrm{ng}, 300 \mathrm{ng}$ and $150 \mathrm{mg}$ respectively of each of the low m.wt. marker proteins. The marker dye comigrated with lactalbumin in the gel.

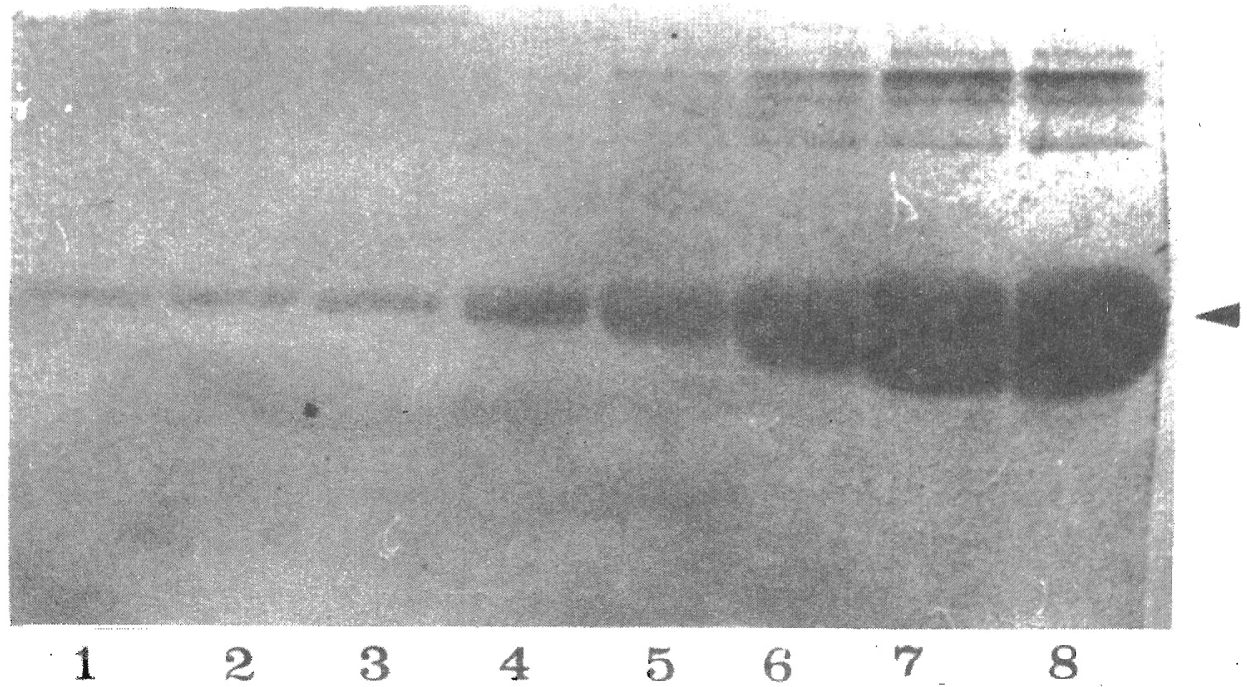

Figure 2: Variation in the mobiesty of the beavy chain of human IgG with protein concentration. Lanes 1.8 were loaded with $375 \mathrm{ng}, 750 \mathrm{ng} .1 .5 \mu \mathrm{g}, 3.1 \mu \mathrm{g}, 6.25 \mu \mathrm{g}, 12.5 \mu \mathrm{g}, 25 \mu \mathrm{g}, \mathrm{x}_{\mathrm{g}} \mathrm{n}, 50 \mathrm{~g}$ of IgG respectively. The migration of the IgG heavy chain is indicated by an arrow. 
products of enzymatic reactions. However in both these procedures neither the middle or the leading edge of the detected bands will yield the best estimate of mobility where proteins are overloaded.

\section{Acknowledgements}

This work was supported in part by grants from the International Atomic Energy Agency and the UNDP/World Bank/WHO Special Programme for Research and Training in Tropical Diseases.

\section{Reference}

1. Laemmli U.K. (1970). Cleavage of structural proteins during the assembly of the head of the bacteriophage T4. Nature 227:680-685. 